\title{
Study on vitamin D receptor gene polymorphisms in patients with urinary tract infections conducted in Northwestern Mexico
}

\section{Estudio de los polimorfismos del gen del receptor de vitamina $D$ en pacientes del noroeste de México con infección urinaria}

Denisse Stephania Becerra-Loaiza, ${ }^{1}$ Jorge Guillermo Sánchez-Zazueta, ${ }^{2}$ Luis Antonio Ochoa-Ramírez, ${ }^{1}$ Ismael Velarde-Rodríguez, ${ }^{3}$ José Rodríguez-Millán, ${ }^{4}$ Jesús Salvador Velarde-Félix ${ }^{1,2,5}$

\begin{abstract}
OBJECTIVE: To evaluate the influence of the polymorphisms of the vitamin D receptor gene (Fokl: rs2228570, Bsml: rs1544410, Apal: rs7975232, and Taql: rs731236) on the clinical parameters of patients with urinary tract infections.

MATERIALS AND METHODS: A comparative, prospective, and cross-sectional study was conducted at the Hospital General de Culiacán Dr. Bernardo J. Gastélum within the time frame of August 2016 to July 2017. The polymorphisms were detected through the polymerase chain reaction-restriction fragment length method in 119 patients diagnosed with urinary tract infection and in 206 individuals with no urinary tract infection. The data analysis was carried out using the $\chi^{2}$ and odds ratio (OR) with a $95 \%$ confidence interval $(95 \% \mathrm{Cl})$. The logistic regression method, adjusted by age and sex, was employed to evaluate the relation between clinical characteristics and genotypes, utilizing the STATA version 13.0 program. Statistical significance was set at a $p<0.05$.

RESULTS: We found differences in the prevalence of the CA-Apal genotype between the study groups. The Fokl and Bsml polymorphisms and the TGAT and CGCT haplotypes were associated with certain clinical characteristics.

CONCLUSIONS: A possible link between the vitamin D receptor gene and bacterial urinary tract infection in a Mexican population was suggested.

KEYWORDS: Vitamin D receptor; Urinary tract infection; Polymorphisms; Haplotypes.

Resumen

OBJETIVO: Evaluar la influencia de los polimorfismos del gen del receptor de vitamina D (Fokl: rs2228570, Bsml: rs1544410, Apal: rs7975232 y Taql: rs731236) en los parámetros clínicos de pacientes con infección de la vía urinaria.

MATERIALES Y MÉTODOS: Estudio comparativo, prospectivo y transversal, Ilevado a cabo en el Hospital General de Culiacán Dr. Bernardo J. Gastélum, entre agosto de 2016 y julio de 2017. Los polimorfismos se detectaron mediante reacción en cadena de la polimerasa PCR. Para el análisis de los datos se utilizó la prueba de $\chi^{2}$ y la razón de probabilidades (OR), con intervalo de confianza de 95\% (IC95\%); con la intención de evaluar la relación entre las características clínicas y los genotipos se implementó la prueba de regresión logística ajustada por edad y sexo, con el programa STATAv13.0. Se consideró estadísticamente significativo el valor de $\mathrm{p}<0.05$.

RESULTADOS: El corte con enzimas de restricción se efectuó en 119 pacientes con diagnóstico de infección de la vía urinaria y en 206 individuos sin infección. Se encontraron diferencias en la prevalencia del genotipo CA-Apal en ambos grupos de estudio. Los polimorfismos Fokl y Bsml, y los haplotipos TGAT y CGCT se asociaron con algunas características clínicas.

CONCLUSIONES: Se sugiere un posible vínculo entre el gen del receptor de vitamina D y las infecciones bacterianas de la vía urinaria en la población mexicana.

PALABRAS CLAVES: Receptor de vitamina D; infección de la vía urinario; polimorfismos; haplotipos.
\end{abstract}

\author{
${ }^{1}$ Postgraduate Degree in Biomedic \\ Sciences, Chemical-Biologic Sciences \\ Faculty. \\ ${ }^{2}$ Immunogenetic and Evolution Academic \\ Body UAS-CA-265, Biology Faculty. \\ ${ }^{3}$ Medicine Faculty, Universidad Autó- \\ noma de Sinaloa, México. \\ ${ }^{4}$ Department of Internal Medicine. \\ ${ }^{5}$ Department of Genomic Medicine.
}

Hospital General de Culiacán Dr. Bernardo J. Gastélum, Culiacán, Sinaloa.

Received: July 2018

Accepted: October 2018

Correspondence

Jesús Salvador Velarde Félix

jsvelfe@hotmail.com

This article should be cited as Becerra-Loaiza DS, Sánchez-Zazueta JG, Ochoa-Ramírez LA, Velarde-Rodríguez I, Rodríguez-Millán J, Velarde-Félix JS. Study on vitamin $D$ receptor gene polymorphisms in patients with urinary tract infections conducted in Northwestern Mexico. Rev Mex Urol. 2018 nov-dic;78(6):419-24.

DOI: https://doi.org/10.24245/revmexurol.v78i6.2419 


\section{INTRODUCTION}

Urinary tract infections are caused by the presence of uropathogens in the genitourinary system and are a severe public health problem. ${ }^{1}$ The clinical manifestations and their severity are produced by both an excessive inflammatory response in the host ${ }^{2}$ and microbial pathogenicity. The most common microbes are Escherichia coli, Klebsiella pneumoniae, Proteus mirabilis, Enterococcus faecalis, and Staphylococcus saprophycticus. ${ }^{1}$

Human genetic factors have also been proposed to modulate the immune response. ${ }^{3}$ Vitamin supplements, such as vitamin D, have been reported to prevent urinary tract infections, ${ }^{4}$ whereas insufficient levels have been associated with risk ${ }^{5}$ and recurrence of urinary tract infections $^{6}$ and a low expression of antimicrobial peptides in urine. ${ }^{7}$

Vitamin D has a pleiotropic effect, acting as an immunomodulator of the innate immune response in the urothelium. It acts through its nuclear receptor, the vitamin $\mathrm{D}$ receptor (VDR), encoded by the VDR gene located at 12q13.11, whose single nucleotide polymorphisms (SNPs) have been previously associated with several infectious diseases, such as urinary tract infection, ${ }^{8}$ tuberculosis ${ }^{9}$, leprosy $_{,}{ }^{10}$ and pertussis ${ }^{11}$ in different populations.

In Mexico, the genetic background of urinary tract infections is unknown. The analysis of the VDR genetic polymorphisms, Fokl, Bsml, Apal, and Taql, could be a starting point.

\section{MATERIALS AND METHODS}

Study subjects

We conducted a comparative, prospective, and cross-sectional study at the Hospital General de
Culiacán, in the state of Sinaloa, Mexico, within the time frame of August 2016 to July 2017. A total of 325 individuals were included in the analysis and classified into two groups, according to their clinical features. Group $1(n=119)$ consisted of the patients with positive bacterial urine culture and urinary tract infection diagnosis made by internists, in accordance with the European Guidelines on Urological Infections of the European Association of Urology (EAU), ${ }^{12}$ and risk factors (e.g., diseases associated with urinary tract infections, previous urinary tract infection, hospitalization, and Foley catheter), excluding those patients with urine culture positive for fungi and mixed flora. Group $2(n=206)$ was composed of healthy controls. They were individuals that had no urinary tract infection and whose urine cultures were negative, but who also presented with the abovementioned risk factors.

The demographic data and the following clinical features were obtained from electronic medical record systems and entered into a database: clinical diagnosis e.g., asymptomatic bacteriuria, cystitis, pyelonephritis, catheter-associated urinary tract infections, and urosepsis; host risk factors according to the 2015 ONERUC classification system of the EAU; signs and symptoms, such as fever, lower urinary tract symptoms, abdominal pain, positive costovertebral angle percussion, nausea/vomiting, tenesmus, constipation, pyuria, proteinuria, and hematuria; associated diseases; previous urinary tract infection; hospitalization; and microbiologic test results.

All participants, as well as their parents and grandparents born in Sinaloa, were included in the analysis. Written statements of informed consent were obtained prior to the study, which was approved by the Office of Research Ethics.

DNA extraction and VDR genotyping

Genomic DNA was obtained from peripheral blood using the DTAB-CTAB method. ${ }^{13}$ The 
VDR polymorphisms (Fokl: rs2228570, Bsml: rs1544410, Apal: rs7975232, and Taql: rs731236) were genotyped using the polymerase chain reaction-restriction fragment length polymorphism method previously described by Shafia et al. ${ }^{14}$ and Li et al. ${ }^{15}$ and visualized in polyacrylamide gel electrophoresis at $6 \%$. Ten percent of our results were randomly selected, then analyzed and confirmed by an independent observer.

\section{Statistical analysis}

For the association analysis between genotypes and urinary tract infection we used the chi-square test and odds ratio (OR) with a 95\% confidence interval. To determine if there was a relationship between the clinical features and genotypes, we used the logistic regression method, adjusted by age and sex. The STATA version 13.0 program was utilized for both evaluations.

The SHEsisPlus free online software ${ }^{16}$ was used to analyze the haplotypes and linkage disequilibrium calculation between the two groups. The level of significance was defined as $p<0.05$.

\section{RESULTS}

\section{Study subjects}

For the patients in group 1 (86 females and 33 males), the mean and standard deviation (SD) of age was $48 \pm 23.03$ and it was $44 \pm 22.38$ for the group 2 healthy controls (109 females and 97 males). The bacterial uropathogens found, in order of prevalence, were: Escherichia coli, Pseudomonas sp, Klebsiella pneumoniae, Enterococcus faecalis, Proteus mirabilis, Acinetobacter baumannii complex, and Serratia odorifera. The clinical features of group 1 are shown in Table 1.

In the group 2 healthy controls, $43.69 \%$ of the subjects had associated diseases, such as diabetes, kidney disease, urolithiasis, sepsis, and
Table 1. Clinical characteristics of patients with urinary tract infections (group 1)

\begin{tabular}{l|c|}
\hline Diagnosis & $\mathbf{n}(\mathbf{\%})$ \\
\hline Asymptomatic bacteriuria & $60(50.42)$ \\
Cystitis & $17(14.29)$ \\
Pyelonephritis & $30(25.21)$ \\
Catheter-associated urinary tract infec- & $7(5.88)$ \\
tions & $5(4.20)$ \\
Urosepsis & \\
Risk factors, classification system & \\
\hline O & \\
R & $20(16.81)$ \\
E & $14(11.76)$ \\
N & $33(27.73)$ \\
U & $23(19.33)$ \\
C & $21(17.65)$ \\
Signs and symptoms & $8(6.72)$ \\
Fever & \\
Lower urinary tract symptoms & \\
Abdominal pain & $43(36.13)$ \\
Positive costovertebral angle percussion & $42(35.29)$ \\
Nausea/Vomiting & $23(19.32)$ \\
Tenesmus & $13(10.92)$ \\
Constipation & $8(10.72)$ \\
Heartburn & $9(7.56)$ \\
Proteinuria & $1(0.84)$ \\
Hematuria & $2(1.68)$ \\
Presence of associated diseases & $3(2.52)$ \\
Previous urinary tract infection & $4(3.36)$ \\
Hospitalization & $73(61.34)$ \\
\hline & $42(35.29)$ \\
\hline & $59(49.58 \%)$ \\
\hline
\end{tabular}

O: NO known/associated Risk Factor (RF); R: Recurrent urinary tract infection RF, but no risk of severe outcome; E: Extra-urogenital RF, with risk of more severe outcome; N: Nephropathic disease, with risk of more severe outcome; U: Urologic RF, with risk of more severe outcome, that can be resolved during therapy; C: Permanent urinary Catheter and non-resolvable urologic RF, with risk of more severe outcome.

prostatic hyperplasia. A total of $25.24 \%$ had presented with a previous urinary tract infection, $56.79 \%$ had been hospitalized, and $12.62 \%$ had required a Foley catheter.

\section{Allelic, genotypic, and haplotypic analysis}

All loci were in agreement with the HardyWeinberg equilibrium, except $A$ pal in group 1 and $B s m \mathrm{l}$ in both groups. Table 2 shows similar, 
Table 2. Distribution of allelic and genotypic frequencies

\begin{tabular}{|c|c|c|c|}
\hline SNP & $\begin{array}{c}\text { Group } 1 \\
n(\%)\end{array}$ & $\begin{array}{c}\text { Group } 2 \\
\text { n (\%) }\end{array}$ & $\begin{array}{c}\text { p-value, OR, } \\
{[95 \% \mathrm{CI}]}\end{array}$ \\
\hline $\begin{array}{l}\text { Fokl } \\
\text { Genotype } \\
\text { TT } \\
\text { TC } \\
\text { CC } \\
\text { Allele } \\
\text { C }\end{array}$ & $\begin{array}{c}35(29.41) \\
53(44.54) \\
31(26.05) \\
(48.31)\end{array}$ & $\begin{array}{c}44(21.36) \\
111(53.88) \\
51(24.76) \\
(51.69)\end{array}$ & $\begin{array}{l}\text { ns } \\
\text { ns } \\
\text { ns } \\
\text { ns }\end{array}$ \\
\hline $\begin{array}{l}\text { Bsml } \\
\text { Genotype } \\
\text { GG } \\
\text { GA } \\
\text { AA } \\
\text { Allele } \\
\text { A }\end{array}$ & $\begin{array}{c}76(63.87) \\
33(27.73) \\
10(8.40) \\
(22.26)\end{array}$ & $\begin{array}{c}130(63.11) \\
56(27.18) \\
20(9.71) \\
(23.30)\end{array}$ & $\begin{array}{l}\text { ns } \\
\text { ns } \\
\text { ns } \\
\text { ns }\end{array}$ \\
\hline $\begin{array}{l}\text { Apal } \\
\text { Genotype } \\
\text { CC } \\
\text { CA } \\
\text { AA } \\
\text { Allele } \\
\text { A }\end{array}$ & $\begin{array}{c}48(40.34) \\
45(37.82) \\
26(21.84) \\
(40.75)\end{array}$ & $\begin{array}{c}63(30.58) \\
108(52.42) \\
35(16.99) \\
(43.20)\end{array}$ & $\begin{array}{c}\text { ns } \\
0.021,0.547 \text {, } \\
{[0.327-0.912]} \\
\text { ns } \\
\text { ns }\end{array}$ \\
\hline $\begin{array}{l}\text { Taql } \\
\text { Genotype } \\
\text { TT } \\
\text { TC } \\
\text { CC } \\
\text { Allele } \\
\text { C }\end{array}$ & $\begin{array}{c}75(63.03) \\
41(34.45) \\
3(2.52) \\
(19.74)\end{array}$ & $\begin{array}{c}128(62.14) \\
65(31.55) \\
13(6.31)\end{array}$ & $\begin{array}{l}\text { ns } \\
\text { ns } \\
\text { ns }\end{array}$ \\
\hline
\end{tabular}

OR: Odds ratio; Cl: Confidence interval; ns: not significant

and therefore not statistically significant, allelic and genotypic frequencies between the two groups prior and subsequent to adjustment for age and sex, except for the CA genotype of Apal, which was more prevalent in the group 2 healthy controls $(p=0.021, O R=0.547,95 \%$ $\mathrm{Cl}=0.327-0.912$ ).

The logistic regression analysis found association between the Fokl-C allele and lower urinary tract symptoms $(\mathrm{p}=0.042, \mathrm{OR}=0.406,95 \% \mathrm{Cl}=$ 0.169-0.969), as well as the Bsml-AA genotype and recurrent urinary tract infections $(p=0.008$, $\mathrm{OR}=8.488,95 \% \mathrm{Cl}=1.767-40.772)$. The remaining variables showed no association.
The haplotype analysis showed linkage disequilibrium between Bsml-Apal-Taql ( $\mathrm{D}^{\prime}>0.90$, $\mathrm{R}^{2}$-Bsml/Apal $=0.40, \mathrm{R}^{2}$-Bsml/Taql $=0.80$, and $\mathrm{R}^{2}$-Apal/Taql=0.36). Six haplotypes were the most representative and showed no differences between the two groups $(p>0.05)$. The most common was TGCT (Table 3).

Finally, the comparison of haplotype frequencies in the group 1 patients, according to the presence/absence of clinical features through the logistic regression model showed an association of the TGAT haplotype with lower urinary tract symptoms $(\mathrm{p} \leq 0.001, \mathrm{OR}=5.448,95 \% \mathrm{Cl}=$ 1.890-15.707) and abdominal pain ( $p=0.006$, $\mathrm{OR}=4.157 .95 \% \mathrm{Cl}=1.401-12.326)$, and of the CGCT haplotype with lower urinary tract symptoms $(p=0.016, \mathrm{OR}=0.341,95 \% \mathrm{Cl}=$ $0.137-0.849)$. The remaining variables showed no association.

Table 3. Haplotype distribution between patients with urinary tract infections and healthy controls

\begin{tabular}{|l|c|c|}
\hline Haplotype & $\begin{array}{c}\text { Patients with urinary } \\
\text { tract infection, \% }\end{array}$ & $\begin{array}{c}\text { Healthy } \\
\text { controls, \% }\end{array}$ \\
\hline TGCT & 37.65 & 35.1 \\
\hline CGCT & 21.5 & 24 \\
\hline CAAC & 14.7 & 14.8 \\
\hline CGAT & 10.55 & 9.2 \\
\hline TGAT & 6.95 & 7.4 \\
\hline TAAC & 4.25 & 3.7 \\
\hline
\end{tabular}

\section{DISCUSSION}

The vitamin D endocrine system plays an important role in modulating the immune response. ${ }^{17}$ In fact, there are several studies that support the association between vitamin $\mathrm{D}$ and bacterial infections, implicating polymorphisms in the VDR gene. $^{8-11}$ Nevertheless, there are presently only two reports on VDR polymorphisms and urinary tract infection. ${ }^{8,18}$ The first, by Garcia-Nieto et al., ${ }^{18}$ 
discarded the Bsml polymorphism as a candidate for a genetic biomarker in Spanish children with idiopathic hypercalciuria and urinary tract infection. The second, conducted by Aslan et al., ${ }^{8}$ proposed Apal as a protective factor against urinary tract infection and Fokl as a predisposing factor in a Turkish pediatric population.

Our study is interesting because it is the first to offer suggestions and proposals about VDR gene polymorphisms in relation to clinical features of urinary tract infections. They are discussed below.

The Apal CA genotype could be a protective factor against bacterial urinary tract infections in individuals with risk factors, as is the case with the Fokl C allele and the CGCT haplotype in lower urinary tract symptoms. In contrast, the Bsml AA genotype could predispose to urinary tract infection recurrence and the TGAT haplotype could increase the risk for developing lower urinary tract symptoms and abdominal pain in patients.

The functional role of the Apal and Bsml polymorphisms is still unknown, but it is possible that they are involved in the mRNA stability of the VDR. ${ }^{17}$ Due to its location in the $3^{\prime}$-UTR, we suggest that both polymorphisms could deregulate vitamin D receptor expression in the urothelium. Thus, we assume that Bsml affects the capacity of vitamin D to enhance the expression of antimicrobial peptides, decreasing the full elimination of bacterial uropathogens, and in turn, favoring urinary tract infection recurrence.

On the other hand, the Fokl genotypes may interact differentially with important transcription factors in the genes of the immune response. ${ }^{19}$ For example, once activated, NFKB enhances IL-6 transcription in bladder epithelial cells. ${ }^{20}$ We believe that could influence the beginning of lower urinary tract symptoms and their severity. Furthermore, Gurocak et al. have shown the hereditary predisposition of lower urinary tract symptoms in some families. ${ }^{21}$ In addition, a protective effect of the TaqI-VDR polymorphism against lower urinary tract symptom development in Japanese, Thai, and Indian men was reported by Cartwright et al. in their meta-analysis. ${ }^{22}$

Moreover, for the haplotypic results, we suggest that the allelic variation in Fokl ( $\mathrm{T}$ or $\mathrm{C}$ allele) on the IGAT/CGCT haplotypes modulates the risk/protection for lower urinary tract symptom development. That has not been proved but could lay the groundwork for interesting future clinical investigations about VDR-vitamin D and its therapeutic potential in urinary tract infections.

Finally, the association found in the present study between abdominal pain in patients with urinary tract infections and the TGAT haplotypes of the VDR gene polymorphism was observed for the first time. However, there are reports on the participation of vitamin D levels and the VDR polymorphisms in the development of different kinds of pain, such as chronic pain, ${ }^{23-24}$ lower back pain, ${ }^{25}$ and knee pain in patients with osteoarthritis. ${ }^{26}$ The manifestation of pain has been explained by the role of vitamin $\mathrm{D}$ in nociceptive and inflammatory pain mechanisms, reducing the release of pro-inflammatory cytokines and suppressing T-cell response. In vitro studies have also shown that vitamin D inhibits the synthesis of prostaglandin E2. ${ }^{27}$

These findings suggest that VDR gene polymorphisms have a possible role in the clinical features of urinary tract infection. Nevertheless, they raise more questions than answers. Clinical trials must be conducted to test the results of our study and rule out any random effects that may have occurred.

\section{Acknowledgments}

This work was supported by PROFAPI/UAS (PROFAPI2015/269). DSBL was a student in the Biomedical Sciences Masters Program at the 
Sinaloa Autonomous University and received fellowship 413348 from the CONACYT. We thank MSc César Rómero-Higareda and all the participants that made this project possible.

Finally, special thanks to José Guadalupe Rendón-Maldonado, PhD, of the Biomedical Sciences Masters Program, Sinaloa Autonomous University, for his judicious observations.

\section{REFERENCES}

1. Flores-Mireles AL, et al. Urinary tract infections: epidemiology, mechanisms of infection and treatment options. Nat Rev Microbiol 2015;13(5):269-84. DOI: 10.1038/nrmicro3432

2. Godaly G, Ambite I, Puthia M, et al. Urinary tract infection molecular mechanisms and clinical translation. Pathogens 2016;5(1):E24. DOI: 10.3390/pathogens5010024

3. Ragnarsdóttir B, et al. Genetics of innate immunity and UTI susceptibility. Nat Rev Urol 2011;8(8):449-68. DOI: 10.1038/ nrurol.2011.100

4. Hertting $\mathrm{O}$, et al. Vitamin $\mathrm{D}$ induction of the human antimicrobial peptide cathelicidin in the urinary bladder. PLoS One 2010;5:e15580. DOI: 10.1371/journal.pone.0015580

5. Tekin $M$, et al. The association between vitamin $D$ levels and urinary tract infection in children. Horm Res Paediatr 2015;83(3):198-203. DOI: 10.1159/000370046

6. Nseir W, et al. The association between serum levels of vitamin $D$ and recurrent urinary tract infections in premenopausal women. Int J Infect Dis 2013;17(12):e1121-4. DOI: 10.1016/j.jijid.2013.06.007

7. Övünç-Hacıhamdioğlu $D$, et al. The association between serum 25-Hydroxy Vitamin D level and urine cathelicidin in children with a urinary tract infection. J Clin Res Pediatr Endocrinol 2016;8(3):325-9. DOI: 10.4274/jcrpe.2563

8. Aslan $\mathrm{S}$, et al. Vitamin $\mathrm{D}$ receptor gene polymorphism in children with urinary tract infection. Pediatr Nephrol 2012;27(3):417-21. DOI: 10.1007/s00467-011-2000-0

9. Kinnear $\mathrm{C}$, et al. The role of human host genetics in tuberculosis resistance. Expert Rev Respir Med 2017;11(9):721-37. DOI: 10.1080/17476348.2017.1354700

10. Velarde-Félix JS, et al. Association between the Taql polymorphism of the vitamin $D$ receptor gene and lepromatous leprosy in a Mexican population sample. Salud Publ Mex 2009;51(1):59-61. Dirección URL: < https:// scielosp.org/scielo.php?script=sci_arttext\&pid=\$0036$36342009000100011 \& \operatorname{lng}=$ en\&nrm=iso\&tlng=en>.

11. Han WG, Hodemaekers HM, Nagarajah B, et al. Association of Vitamin D Receptor polymorphism with susceptibility to symptomatic pertussis. PLoS One 2016(2);11:e0149576. DOI: 10.1371/journal.pone.0149576

12. EAU (European Association of Urology). Guidelines on Urological Infections. European Association of Urology, 2015.
Available at https://uroweb.org/wp-content/uploads/19Urological-infections_LR2.pdf. Accessed January 2018.

13. Gustincich $\mathrm{S}$, et al. A fast method for high-quality genomic DNA extraction from whole human blood. Biotechniques 1991;11(3):298-300,302.

14. Shafia $S$, et al. Role of vitamin $D$ receptor (VDR) polymorphisms in susceptibility to multiple myeloma in ethnic Kashmiri population. Blood Cells Mol Dis 2013;51(1):56-60. DOI: 10.1016/j.bcmd.2013.02.001

15. Li K, et al. The association of vitamin $\mathrm{D}$ receptor gene polymorphisms and serum 25-hydroxyvitamin D levels with generalized vitiligo. Br J Dermatol 2012;167(4):815-21. DOI: 10.1111/j.1365-2133.2012.11132.x

16. Shi YY, He L. SHEsis, a powerful software platform for analyses of linkage disequilibrium, haplotypes construction, and genetic association at polymorphism loci. Cell Res 2005;15(2):97-8. DOI: 10.1038/sj.cr.7290272

17. Uitterlinden $A G$, et al. Genetics and biology of vitamin $D$ receptor polymorphisms. Gene 2004;338(2):143-56. DOI: 10.1016/j.gene.2004.05.014

18. García Nieto $\mathrm{V}$, et al. Vitamin D receptor polymorphisms and susceptibility to developing urinary tract infection in children diagnosed with idiopathic hypercalciuria. Nefrologia 2002;22(4):390-1.

19. Zeljic K, et al. Vitamin D receptor gene polymorphisms association with the risk of sepsis and mortality. Int J Immunogenet 2017;44(3):129-34. DOI: 10.1111/iji.12318

20. Spencer JD, et al. The innate immune response during urinary tract infection in pyelonephritis. Pediatr Nephrol 2014;29(7):1139-49. DOI: 10.1007/s00467-013-2513-9

21. Gurocak $S$, et al. The impact of gene polymorphisms on the success of anticholinergic treatment in children with overactive bladder. Dis Markers 2015;2015:732686. DOI: $10.1155 / 2015 / 732686$

22. Cartwright $R$, et al. Systematic review and meta-analysis of candidate gene association studies of lower urinary tract symptoms in men. Eur Urol 2014;66(4):752-68. DOI: 10.1016/j.eururo.2014.01.007

23. Hicks GE, et al. Associations between vitamin D status and pain in older adults: the Invecchiare in Chianti study. J Am Geriatr Soc 2008;56(5):785-91. DOI: 10.1111/j.15325415.2008.01644.x

24. Karras $S$, et al. Vitamin D in fibromyalgia: A causative or confounding biological interplay? Nutrients 2016;4(6):E343. DOI: 10.3390/nu8060343

25. Cauci S, et al. Low back pain and Fokl (rs2228570) polymorphism of vitamin D receptor in athletes. BMC Sports Sci Med Rehabil 2017;9:4. DOI: 10.1186/s13102-017-0069-x

26. Muraki $S$, et al. Association of vitamin D status with knee pain and radiographic knee osteoarthritis. Osteoarthritis Cartilage 2011;19(11):1301-06. DOI: 10.1016/j. joca.2011.07.017

27. Helde-Frankling M, Björkhem-Bergman L. Int J Mol Sci 2017;18(10):E2170. DOI: 10.3390/ijms18102170 